Nicholai Studies, Vol. I, No. 1 (2021): 203-208. DOI: https://doi.org/10.46825/nicholaistudies/ns.2021.1.1.203-208 UDC: 271.222(497.11)-726.2-36:929 Николај Велимировић, свети(049.32) 94(497.11)"19"(049.32)

Received: October $8^{\text {th }}, 2020$. Accepted: December $22^{\text {nd }}, 2020$.

\title{
Bojan Belić, Bishop Nicholai, Hitler and Europe: Controversies
}

Valjevo 2019, 259 p.

[In Serbian: Бојан Белић, Влаgика Николај, Хийлер и Евройа: конитроверзе. Ваљево: Ваљевска гимназија, 2019. 259 стр. ; фотогр. ; 24 cm. ISBN 978-86-85419-13-3]

A book by Bojan Belić entitled Bishop Nicholai, Hitler and Europe: Controversies was published recently. An expert review for this publication was written by Dr. Veljko Đurić Mišina, the director at the Museum of Genocide Victims in Belgrade, and Milorad Belić, a retired history professor. The most important facts regarding Bishop Nicholai's stay in Dachau are presented in Bojan Belićs book, a few of which are lesser-known to the Serbian audience, as well as the facts regarding his relation to Nazism, anti-Semitism, and Europe.

This publication brings out the data collected based on relevant sections taken from sources and literature in English and German language. One of the special features of this book is that it is written in a form of a discussion so it is abundant in polemical tones, mainly criticizing the conclusions reached by certain authors and a number of researchers who dealt with Bishop Nicholai's actions and fate prior to and during WW2.

According to Dr. Veljko Đurić Mišina (an excerpt from his review has been printed on the back cover of the book), this 
work has several valuable characteristics: "among which the most important is that the author went through the effort of finding and later using numerous works on the relevant topic published in several languages".

A preface (pp. 5-6) is followed by a chapter entitled "From Ljubostinja and Vojlovica to Dachau" (pp. 7-41) in which Belić is looking back at the assumptions and claims regarding Bishop Nicholai's fate during WW2 brought up by Predrag Ilić, Jovan Bajford, Mirko Đorđević, Filip David, Aleksandar Lebl and other authors who criticized Bishop Nicholai's actions and positioning in the context of Nazi politics. Those claims are being confronted by Belić, he is using testimonies taken from relevant documents, testimonies of Nazi detainees held in captivity during WW2, etc.

In the chapter entitled "An honorary bunker" (pp. 42-111), Belić explains why this title does not imply an honor conferred on detainees, comparing testimonies from historical records with the information on Bishop Nicholai's and Patriarch Gavrilo Dožić’s stay in Dachau. Belić says:

\footnotetext{
“'Ehrenbunker' was not some kind of an honorary bloc for guests of Nazi regime, it was a claustrophobic line of narrow damp hallways, weighted by heavy, dense, walls without windows, or a wall with a tiny window with bars, there was an interrogation room and possibly a room for physical punishments, surrounded by guardhouses, and in the yard there was a wall designated for executions by firing squad...” (p. 43).
}

The man who organized the unsuccessful attempt to assassinate Adolf Hitler - Johann Georg Elser (1903-1945), a German theologian and later a Bishop of Munich Johannes Neuhäusler (1888-1973), a French politician and prime minister Léon André Blum (1872-1950), the French army general and one of the leaders of the Resistance Charles Delestraint (1879-1945), Pastor Martin Niemöller (1892-1984) and other enemies of Nazi regime were imprisoned in this bunker which 
contained 137 separate cells (p. 45). Serbian Church leaders were also held captive in the same camp block as some other Hitler's opponents and the prisoners of Nazi Reich, as Belić points out in this chapter, by collecting very useful and striking testimonies of witnesses, prisoners who survived terrors of concentration camps, as well as by collecting testimonies from other materials and relevant literature.

In a chapter entitled "Subcamp Schliersee" (pp. 112-133) the author shows that Dachau was not just a single camp, it was rather a system of camps - a complex which "was comprised of 77 sidecamps and subcamps (some of which were remote and more than $200 \mathrm{~km}$ away), like Itter and Schliersee" (p. 113). This being said, it would not be accurate to consider the stay of Bishop Nicholai and Patriarch Gavrilo in Iter and Schliersee as their release, which was readily concluded by a number of the previous researchers. On the contrary, as these sub-camps were administratively dependent on the central camp in Dachau, this would mean that Serbian bishops were detained in the Dachau camp complex both at the end of 1944 and dur-

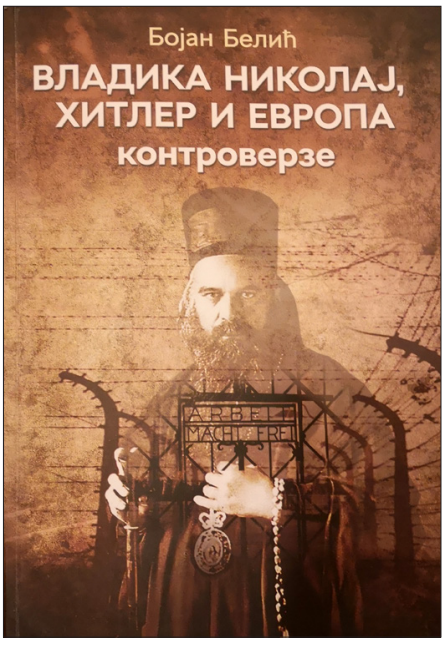
ing the first few months of 1945, which to a significant extent redefines the approach to the question of the duration of their captivity in Nazi camp conditions, which in some studies was reduced to a couple of weeks of an honorary visit to Dachau during September or October 1945.

In the most extensive chapter of the book, entitled "Bishop Nicholai on Nazism, Jews and Europe" (pp. 134-246), the author first offers a kind of comparative analysis of the reception of Nazi politics during the 1930s, thus indicating that, in the broader context of international relations, firstly in the context of Western European and also Eastern European and especially Soviet politics of that time, intellectual and cultural 
movements and life in general, the danger of Nazism was not immediately recognized.

In the thematic respect, the focus of this chapter shifts to a broader level, and it deals with additional issues concerning the attitude of Orthodox Church dignitaries towards Bolshevism, the anti-Semitism which characterized actions and thoughts of individual politicians and creators who put a decisive stamp to the history and culture of $20^{\text {th }}$ century, the problem of modern Serbian auto-chauvinists who did not try to approach these topics in an impartial way and, who have, by ignoring certain facts, through biased interpretation in the scientific community, among other things, introduced the image of Bishop Nicholai as an anti-Semite, Nazi ideologue, stupid chauvinist, etc. The topics of this chapter extend even to the problems of recent European history, the French Revolution (pp. 204-209), German idealist philosophy (pp. 210), and so on.

In the methodological sense, the presentation of the author's insights in this chapter becomes, at times, congested with the amount of information he processes and interprets, and it is very demanding to follow it. It is assumed that, for the sake of method, it would have been better to divide this chapter into several shorter chapters or subchapters, in which certain topics would be treated separately. At the same time, the question arises as to whether and to what extent it is justified to open so many questions and raise so many topics in a book dedicated to controversies related to the character of Bishop Nicholai.

On the other hand, the effort to gather and analyze so much information, that are to some extent important for the basic issue that the author dealt with, and the result he presented in his book, are both very valuable and will greatly facilitate the work of future researchers. First of all, certain data that Belić came across in the Serbian scientific community were partially known or even completely unknown, and in that sense, this book has a lot to offer to the interested reader.

Two essential remarks that we would give to the mentioned chapter would concern the interpretation of the work known 
under the title To the Serbian People Through the Dungeon Window (pp. 184-197). Namely, we believe that, before interpreting this work, one should first examine it critically, i.e. approach the issues of authorship, origin, and authenticity of this work, which was published for the first time three decades after the death of Bishop Nicholai, in circumstances that are not clear, and which bind to some caution at least.

In addition, it is a real pity that the author did not pay attention to the ecumenical activities of Bishop Nicholai in the context of the anti-Nazi initiative of inter-Christian ecumenical organizations during the 1930s, for example in the context of Velimirovich's involvement in the activities of the Universal Christian Conference for Life and Work, i.e. Commissions for Life and Work and the World Alliance for International Friendship through the Churches. The mentioned bodies were already in September 1933, after the annual conference of the Commission for Life and Work held in Novi Sad, in which Bishop Nicholai also participated, as well as at the meeting of the Executive Board of the World Alliance held a few weeks later in Sofia, as a result of joint efforts, through appropriate statements publicly announced their position - a clear and very negative attitude towards Hitler's racist policy, rejecting the so-called "Arian paragraph" and the then Nazi agenda as anti-evangelical and anti-Christian. The consequences of this attitude were far-reaching and very significant, and we believe that, on the other hand, Nicholai's participation and support for these early anti-Nazi initiatives was one of the reasons he was characterized as a mortal enemy in the eyes of the Nazi regime even before the war, as the one who should be removed from public life as soon as possible.

However, a critical research of Bishop Nicholai's legacy is yet to come, and publications such as this one are an important and significant step toward overcoming the uncritical and frivolous approach to the issues of Velimirovich's thought, as well as to the issues of his life and work. In that sense, our remarks should be understood as a support 
for Belićs research efforts, and encouragement for him to continue his diligent and dedicated work, because there are many open questions regarding the life and work of Bishop Nicholai, but only a few clear and precise answers and a few thorough and objective researchers.

In general, Belićs book brings a large number of very useful and interesting data, from a perspective that has been largely neglected by previous researchers. There is a list of used literature at the very end of the book (pp. 249-258). Unfortunately, the publication is not equipped with an index of names, or subjects, which, given the density of data collected in this book, would be a necessary tool and key to use all the valuable information contained in it. We believe that it would be very useful if a possible second edition of this publication would be equipped with indices of names and subjects, or at least with an index of names.

In a technical sense, this publication should be addressed in terms of spelling errors, i.e. certain shortcomings concerning the poorly done proofreading part of the work, as well as the typeface and preparation for printing; so for example, pagination according to the content brought on p. 259 does not correspond to the actual pagination of the chapters in the book.

But regardless of these minor shortcomings, Bojan Belić's book brings valuable insights to Serbian readers and invites the scientific community to reconsider the ruling qualification of Bishop Nicholai Velimirovich as a collaborator of Nazis, a supporter of Hitler, and an anti-Semite. The valuable work of Mr. Belić in collecting and analyzing sources and materials relevant to this topic deserves every praise. 